\title{
Role of Government in Ensuring Safety Consciousness During Mineral Mining Activities in Nigeria
}

\author{
Faisal Emetumah, MSc \\ Anthony Okoye, PhD
}

Department of Environmental Management, Nnamdi Azikiwe University, Awka, Nigeria

Doi:10.19044/esj.2018.v14n20p165 URL:http://dx.doi.org/10.19044/esj.2018.v14n20p165

\begin{abstract}
There are a lot safety issues bordering on events that are taking place in various mineral mining sites including destruction of lives, properties and environmental degradation which have been reported across Nigeria. These issues are further exacerbated because being aware of safety regulations and procedures does not necessarily imply that they will be adequately enforced or complied with. The study looked at the role of government in ensuring safety consciousness during mining activities in Nigeria, by identifying regulatory frameworks, enforcement and compliance issues as well as government mechanisms on safety during mining activities. Reviewed literature showed that there is no holistic regulatory framework on safety management; enforcement and compliance of safety regulations is plagued by corruption and ineptness. Safety issues were usually at the discretion of mining companies and implementing existing safety regulations was challenging and ineffective. The study concluded that the success or failure of government actions is vital in ensuring safety consciousness during mining activities in Nigeria. The study recommends a more comprehensive evaluation of environmental and safety consciousness during mining activities among others.
\end{abstract}

Keywords: Safety consciousness, Nigeria, mineral mining, government

\section{Introduction}

The importance of mining activities to the Nigerian economy is clearly demonstrated by the fact that Nigeria is mostly concerned with exploration, exploitation and exportation of natural resources with less emphasis on processing them. Mineral mining activities provide reasonable foreign exchange earnings as most of these natural resources are sold and utilized outside Nigeria (Abdulkadir, 2014). Nigeria like most African countries today, 
is a by-product of European imperialism whose main purpose was for the exploration as well as exploitation of natural resources used in the economic emancipation of 19 th and 20th century Europe. The colonialists were quick to explore Nigeria for mineral resources by conducting seismic surveys because they wanted to replicate their successes in the Middle East were they found large petroleum resources in the early 20th century (Owen, 2008). According to Baiyewu-Teru (2015), a British mining engineer Albert Kitson was scouting for silver in 1909 around the Udi ridge axis of present day Enugu state. He discovered coal instead and that began a new era for mining in southern protectorate. Similarly, tin mining was vital in the development of Jos plateau area in northern Nigeria even before the 1914 amalgamation. By 1909, Champion (Nigeria) Tin Field Company had obtained mining licenses in the northern protectorate and was pivotal in mining expansion as far as Bauchi province (Raji \& Abejide, 2014).

However, the substitution of coal with petroleum for powering trains as well as electricity generation following the discovery of oil and gas in the late 1950s were militating factors against the growth of the mining sector (Alexander, 2012). In addition, the Nigerian civil war significantly reduced the potentials for mining as many indigenous and expatriate workers abandoned the sites which have relatively remained that way ever since (Ekundare, 1973). Furthermore, 21st century scientific realization of the pernicious impact of greenhouse gases on the environment has weakened the resolve of successive Nigerian governments to revitalize mining of minerals like coal since the return to democratic rule in 1999 (Chindo, 2011).

Nigeria is blessed with significant quantities of mineral resources. As at June 2014, Nigeria had over 390 million metric tons of proven coal deposit and over 1.1 billion metric tons of unproven coal deposits in Anambra, Benue, Enugu and Kogi states (KPMG Report, 2014). Similarly, Bitumen/tar sands/heavy oil deposits in Southwest Nigeria (Ondo state) are estimated at over 55 billion barrels while iron ore deposits in the northcentral, north east and south eastern regions are estimated at over 800 million tons (KPMG, 2012). Despite these abundant mineral resources, Nigeria has been unable to kick-start the mineral mining sector. This is attributed mainly to overdependence on petroleum which has made the government lazy and slow in making significant success in developing an economically competitive mineral mining sector (Ogbonna \& Ebimobowei, 2012). Nevertheless, the Federal Government is making the appreciable investment to turn the mining sector around as plans are currently in place to secure $\$ 150$ million funding from international development partners for injection into the Nigerian mining sector (Onwuemenyi, 2017)

It is fundamental that mineral mining activities are carried out under conditions that portend the least possible harm to mining practitioners, 
visitors, host communities and the immediate biophysical surroundings of the mining site. This fundamentality is paramount because undertaking mineral mining activities in unsafe conditions portents a lot of risk potentials which may include; destruction of lives and properties, serious financial losses, tarnishing of the image of mining companies, expensive legal battles among other setbacks. According to an Associated Press (2014) Report, a number of mining accidents have taken place between 2005 and 2013 which resulted in the loss of lives and significant destruction of infrastructure the world over. The recent mining disaster in Iran where over 20 people lost their lives as well as other mining accidents in the past year all explicate the danger of mining under unsafe conditions (Grenfell, 2017). Furthermore, the importance of safety during mining activities is very crucial when it is realized that mining activities are some of the most dangerous procedures in exploiting the mineral resource. Therefore, any entity that wants to succeed in the mining sector must consider safety issues as an integral part of the entire process. When mining activities are safely carried out, a lot of gains are accruable to the employers and their employees. Social responsibility in providing a safe work environment is in order to avoid civil and criminal litigations which may arise when accidents occur. Moreover, organizations that have a positive safety culture where all stakeholders are safety conscious usually stand to gain a lot economically as accidents are usually expensive to mitigate (RMS, 2013). However, the gains of safety can only be realized when all stakeholders are fully aware and conscious of the consequences of doing nothing. Therefore, safety consciousness provides the knowledge, skills, attitude, mindset, and procedure that are required to ensure that people conduct themselves as safe as possible. On that note, all mineral mining activities within Nigeria are subject to the laws, regulations, and guidelines of the country. No one can legally undertake any mining activity without the knowledge and approval of the Federal Government. Therefore, it is important to understand the role of government in shaping safety consciousness during mineral mining activities.

\section{Statement of the problem}

There are serious concerns about working conditions and procedures of undertaking mining activities in many parts of Nigeria which is supposedly covered by government regulations. These concerns are mainly due to issues on incidents during the extraction process which may result in significant injuries, loss of lives, destruction of property and equipment as well as an overall reduction in environmental quality (Nnabo, 2015; Ofoegbu et al., 2013; Oti \& Nwabue, 2013; Onyeobi \& Imeokparia, 2014; Onwuemesi, Ajiwe, Okoye, Nnodu \& Onuba, 2011). The 2010 lead poisoning crisis (between 200 and 400 children died) discovered at gold mining sites in Zamfara State by the international humanitarian organization, Médecins sans 
Frontières clearly points toward the consequence of safety anomalies during mining activities in Nigeria (MSF, 2012). Despite advancements in science and human development, we still do not have a comprehensive, procedural and systematic explanation on the ability to perceive consciousness because being aware and informed on measures to take in order to avoid a dangerous situation does not necessarily imply adequate enforcement and compliance (Tononi, 2008; Koch, 2009). Furthermore, the challenge of data availability on various categories of mining accidents by government agencies in Nigeria is a clear hindrance in understanding safety consciousness during mining activities. In addition, the realization required in providing the needed awareness and understanding of the importance of safety is lacking not only during mining activities but in most sectors of the Nigeria economy (Emetumah, 2016). Regulations on mining activities during the colonial and military eras did not make adequate provisions for the safety and wellbeing of employees that worked in mines. Government legislative frameworks in the current democratic era have some provisions on safety but operationalizing these provisions is seemly ineffective given prevailing safety concerns and anomalies in the Nigerian mining sector. All these issues imply that government is yet to fulfill, its obligation of protecting miners by ensuring adequate enforcement and compliance with relevant regulations.

The aim of the study is to consider the role government plays in shaping safety consciousness during mining activities in Nigeria with the view of expounding implications of this role. This aim will be achieved by identifying legislations and regulations, ascertaining enforcement and compliance issues as well as recognizing mechanisms instituted by the government in regulating safety during mineral mining activities in Nigeria.

\section{The concept of Environmental Consciousness}

The concept of environmental consciousness is based on the assertion that being aware and knowledgeable about hazards and risks involved in any given activity does not necessarily imply compliance and adherence to standards and procedures. Environmental consciousness provides the prerequisite intuition required in enhancing awareness and perception on environmental issues that affect us every day. This is because our awareness and perception on environmental issues are very trendy given that political and socio-economic dimensions of these issues are relevant in a highly globalized world. According to Ungar (1994), measuring environmental consciousness is quite challenging due to the ambiguities in understanding and defining what consciousness is. On that note, consciousness is multifaceted in composition and its definition is usually based on the context it is being applied in. According to Skinner (2014), consciousness is experiential and the manifestation of its phenomena is multifaceted; it is subservient to 
observations, feelings as well as sensations in question. Therefore, consciousness helps us to coherently perceive a phenomenon so that we can make intelligible assertions about that phenomenon.

Zelezny \& Schultz (2000) and Sánchez \& Lafuente (2010) considered the concept of environmental consciousness as precise psychological features that shape the behavior of a person in terms of partaking in environmentally friendly activities. These features were affirmed as attitudinal in determining the extent to which an individual will engage in pro-environmental activities and are different from other psychological factors which may also be relevant in environmental consciousness. In addition, the concept of environmental consciousness in this context clearly departs from its multi-faceted characterizations by Skinner (2014) and Ungar (1994). Sequel to that, the concept of environmental consciousness in the context of its precise psychological features encompasses four psychological dimensions (see figure 1): Affective, Dispositional, Active and Cognitive.

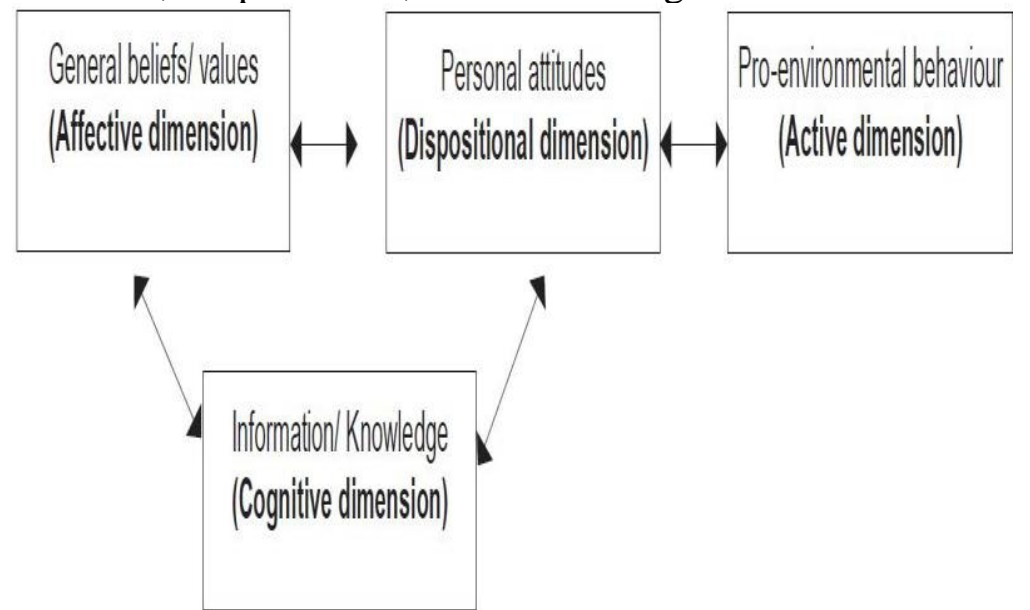

Figure 1: Dimensions of Environmental Consciousness (Sánchez \& Lafuente, 2010).

\section{Framework of Government control and Safety Consciousness during mineral mining activities in Nigeria}

The framework design looks at the relationship between government control and safety consciousness. It is based on the concept of environmental consciousness described in figure 1 . Government control provides guidelines that ensure the safety of all stakeholders in mineral mining through legislations and regulations. These legislations and regulations are comprehensible when relevant stakeholders are affective (feelings and emotions towards the welfare of environmental components), dispositional and cognitive (tendency or inclination to environmental protection activities due to knowledge and information) as well as active (behavior that will ensure efficacy of the environment). (See figure 2). A systematic interaction between all the 
described facets results in safety consciousness during mining activities in Nigeria.

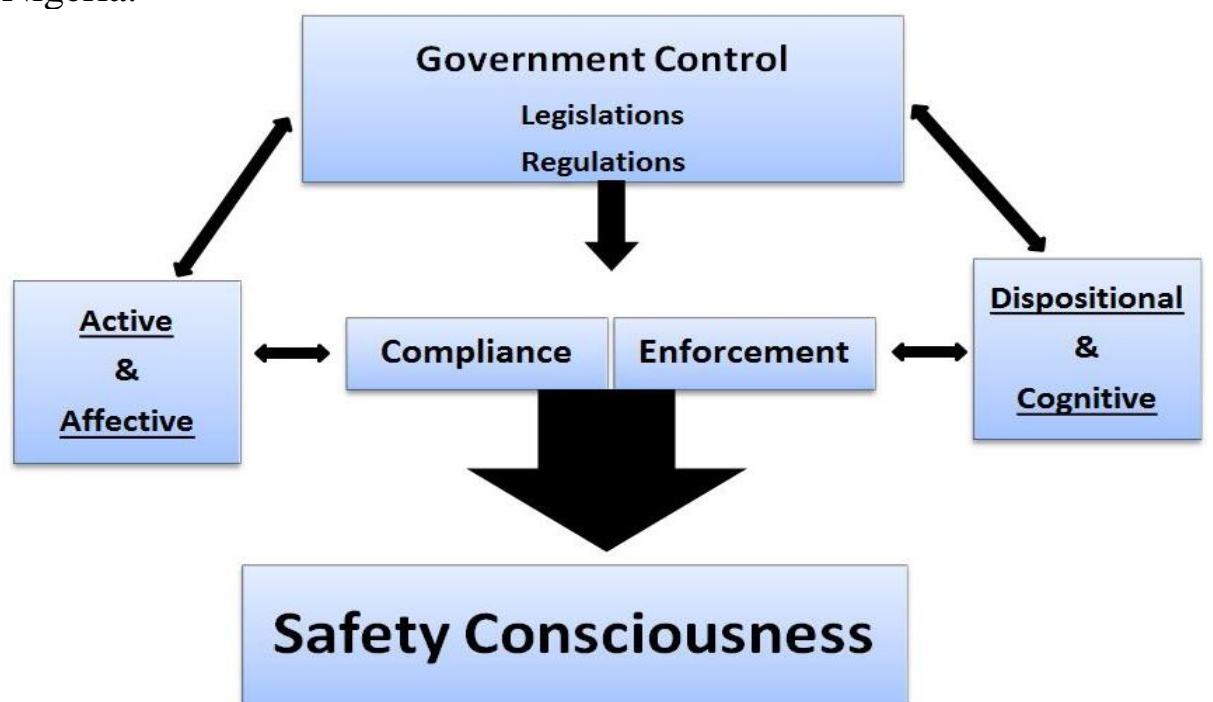

Figure 2: Framework design of Government control and Safety Consciousness during Mineral Mining Activities in Nigeria

\section{Literature Review}

\section{Legislations and Regulations on safety during mineral mining activities}

Legislations in the Nigerian mineral mining sector have always provided authority to the central government. Raji \& Abejide (2014) determined that regulations for mineral mining activities have been in place even before the amalgamation of Nigeria. The British colonialists promulgated the 1907 Southern Nigeria Mining Regulation (oil) Ordinance which clearly differentiated between mining minerals and oil exploration. The separation was necessitated in other to pacify the interests of the British crown in petroleum exploration. The 1907 mining regulation (oil) ordinance did not proffer the rightful privileges and royalties for the indigenous people; it gave the British colonialists overwhelming authority and control over much of the natural resources accruable from mining activities (Carland, 1985). According to Abdulkadir (2014), the 1907 separation between petroleum and other minerals is even more elaborate in 21st century Nigeria when the petroleum industry is completely independent of the mining sector and is mostly under the control multinational companies representing the specific interests of western powers; this has led to immense environmental degradation and pollution in many oil-producing areas in Nigeria. According to Annual Colonial Reports (1914 \& 1916), British colonialists had streamlined their course of action in terms of developing resources accruable from mining by the time of amalgamation in 1914. Review of these reports show that the 1914 
and 1916 mining and oil Ordinances restructured exploration of natural resources such that it became a fully British affair. Their provisions and mandates were designed for only British subjects in both Great Britain and British colonies. Furthermore, the Ordinances as highlighted in the colonial reports made it clear that the natives and indigenes were subservient to any individual(s) or companies authorized by the colonial authorities though some provisions were made on compensation for crops and farmlands destroyed during mining activities (1914 Annual Colonial Report, p13-16; 1916 Annual Colonial Report, p17). Obiakor \& Agajelu (2016) asserts that in order to explore and extract mineral resources in colonial Nigeria, the British instituted mechanisms for administration, banking and transportation; the railway system was very necessary since it was the most effective transportation system available at that time. Therefore, British investments in transportation in Nigeria were to facilitate the evacuation of natural resources. According to Raji \& Abajide (2013), Shell BP which played no small part in environmental pollution in Nigeria, was able to increase production in oil output towards the end of the 1960s despite the civil war taking place in southeastern Nigeria. Furthermore, it was only towards the end of Nigeria civil war in 1969 that a regulatory modification was made in the form of the Petroleum Act of 1969 aimed at solidifying federal control of petroleum mineral resources geographically located in the defunct State of Biafra.

Furthermore, the indigenization movement which swept many African countries in the 1970s was also detrimental to mineral mining activities in Nigeria (Adeniji, 2004). This is because there were no replacements for expats that left due to local financial, technical and infrastructural incapacity. The return of democratic rule in 1999 led many experts and stakeholders to call for a comprehensive and specific legislation on mining activities in Nigeria. According to Adefulu (2010), the Minerals and Mining Act, No. 34 of 1999 which was hurriedly enacted at the return to democratic rule, fell short in many ways and required significant modification to make it effective. Considering the pollution issues brought about by petroleum exploration in Nigeria (UNEP, 2011), environmental considerations were clearly not made in the Minerals and Mining Act, No. 34 of 1999 (Adeniji, 2007). The Nigerian Mineral Mining Act of 2007 which was a replacement for the 1999 Act is the current legislative framework for mining activities in Nigeria. The Act defined minerals as any solid, liquid or gaseous substance found in/on the earth crust as a result of geological activities. Some of these minerals include rocks, coal, coal bed gases, bituminous shale, tar sand and mineral water excluding petroleum resources as well as water resources without minerals (Nigerian Minerals \& Mining Act No.20, 2007). According to the Environmental Law Institute (2014), the National Minerals and Metals Policy of 2008 was designed to have a holistic approach that will ensure that all stakeholders, 
particularly low capital miners are adequately provided for and covered by the law.

\section{Enforcement and Compliance issues}

Generally, promulgation of regulatory frameworks is important in maintaining safety as they help in preserving regularity (Idoro, 2011; Kalejaiye, 2013). Thy also facilitates enforcement and compliance (Anderson, 2007; Diugwu, Baba, \& Egila, 2012). Umeokafor, Isaac, Jones, \& Umeadi (2014) determined that enforcement of safety regulations is the responsibility of the Federal Ministry of Labour and Productivity (renamed Federal Ministry of Labour and Employment(FMLE)) whose operations are hampered by deficient legislations, weak government institutions, official graft, political interference among others. According to Animashaun \& Odeku (2014), Nigeria lacks a comprehensive health and safety legislation unlike developed countries like Australia and United Kingdom. Similarly, the Factories Act 1955 (Cap F1, 2004) which is suppose to provide enforcement provisions on safety management only applies to enclosed industrial settings and disregards other workplaces which include mining activities. Umeokafor (2017) identified that economic factors, self - regulation incapacity and lack of awareness are the most significant barriers to self - regulation in Nigeria. The study points to the potential viability of self - regulation as a substitute to government regulatory framework mechanisms. According to CIS Report (2006), there were over 5000 registered factories in Nigeria as at 2006 but less than 40 inspectors from the FMLE to carry monitoring and compliance checks at these factories which are scattered all over the country. The report asserts that the few number of inspectors working under the FMLE cannot effectively enforce safety regulations due to the huge number of locations they have to inspect. Idowu \& Iyabo (2017) asserts that apart from having few safety regulatory frameworks that can ensure a safe working environment, most of the Nigerian mineral mining laws are not comprehensive enough to facilitate compliance by employers and employees. Similarly, Health Safety and Environment (HSE) management is still rudimentary in terms of progression with most of its facets derived and implemented mostly from multinational companies operating in Nigeria (Adeogun \& Okafor, 2013). Accident records are important in understanding enforcement and complaince issues. According to Ezenwa (2001), 71 fatalities where recorded out of 3183 reported injuries from a wide range of industrial settings including the coal mining sector between 1987 and 1996. Similarly, Umeokafor et al. (2014) determined that between 2002 and 2012, there was colossal under - reporting of injuries and fatalities in Nigerian workplaces which totalled only 93 and 46 respectively over the 11 year period reviewed. Nonetheless, Majority of the accidents (over 75\%) occurred at night mainly due to management 
incompetence which did not provide the right training for employees in the reviewed industries.

The issue of consciousness manifests in safety when it is realized that being aware and adequately informed on the nature of identified hazards and calculated risks do not guarantee that all measures and directives provided will be adhered to (HSA Guide, 2013). However, You-jun (2010) conducted a study on managing safety performance by coal mines in China and determined that there is a positive relationship between safety investment and safety performance. This is because of the more investment in safety management, the better the performance of the safety management system. According to Abubakar (2015), Nigeria does not have a specific legal framework on health and safety when compared with United Kingdom (UK), United States of America (USA), Australia and China. The Labour, Safety, Health, and Welfare (LSHW) bill of 2012 was yet to be signed into law with far-reaching impact on safety consciousness in Nigeria (Umeokafor et al., 2014). Therefore, management in organizations operating in high risk areas can improve output quality by involving employees in the design and implementation of a suitable health and safety policy based on government regulations (Akpan, 2011). According to Kiani \& Khodabakhsh (2013), there is a significant relationship between being conscious of safety and the type of physical and psychological disorders prevalent. In the same vein, Zamanabadi, Kavousy \& Tehrani (2015) conducted a study to see how Hofstede's cultural dimensions (Individualism-collectivism, uncertainty avoidance, power distance, masculinity-femininity and long-term orientation) affects safety culture perception and concluded that there is no significant relationship between the dimensions and safety culture.

\section{Government mechanisms}

According to the Nigeria Extractive Industry Transparency Initiative Report on the Nigerian Mining sector (NEITI Report, 2011), regulations on safety during mining activities in Nigeria can only be enforced through mechanisms at the discretion of the relevant authorities. In line with the postulates of the NMMA of 2007, Federal Ministry of Mines \& Steel Development (FMMSD) is responsible for regulating the mining sector on behalf of the Federal Government of Nigeria. Due to the multifaceted nature of issues in mining activities, FMMSD collaborates with other relevant government agencies like the FMLE and the Environment Ministry. Under the Act (NMMA, 2007), mining operations can be defined as activities undertaken in order to explore, search, process and handle all mineral resources excluding petroleum and water that does not contain the minerals as designated in the Act (Sections 1-3). Furthermore, the Act stipulates that no individual corporation or group can undertake mining activities without approval of the 
FMMSD's Honorable Minister who coordinates the activities of the FMMSD through a number of mechanisms which guide enforcement and compliance.

\section{Mines Inspectorate Department (MID)}

MID is a mechanism of government that is solely responsible for the procedural operations during mining activities in all active mining sites in Nigeria. According to KPMG Report(2014) on the mining sector in Nigeria, MID is expected to have a database and updated record of all mining activities in Nigeria, administer and implement all safety regulations and standards as stipulated in the Act as well as other relevant statutory requirements during mining activities within the Nigerian territory. According to a NEITI Report (2011), MID is also statutorily mandated to collect royalties and other operational fees on behalf of the Federal Government of Nigeria. The report pointed out that MID collected over 700 million Naira ( over \$350,000) in 2010 alone. Furthermore, MID undertakes surveillance of potential mining sites across the Federation to ensure that the activities of illegal miners and mining companies are disrupted and curtailed. This could inform why the Federal Executive Council (FEC) of Nigeria approved about 38 vehicles in 2016 to facilitate and strengthen this mandate (FMMSD, 2016).

\section{Mines Environmental \& Compliance Department (MEC)}

MEC is exclusively responsible for ensuring that the environmental facets of the NMMA of 2007 are implemented and complied with by relevant stakeholders. It is established by the provision of Section 18 of the Act (Nigerian Minerals \& Mining Act No.20, 2007). The environmental sections cover environmental obligations of mineral title holders as elucidated in Section 118 of the Act (reducing pollution and pollutants derived from mining activities as far as practicable). Similarly, MEC ensures that Environmental Impact Assessment (EIA) is carried out before commencing sizeable mining activities as stipulated in Section 119 of the Act. In addition, MEC supervises the Environmental Protection Fund as well as Environmental Protection programs that will take care of the decommissioning and rehabilitation of depleted mining sites as stipulated in Sections 120 and 121 of the NMMA of 2007. Furthermore, the Act empowers MEC to carry out periodic environmental monitoring and audit of Mineral permit and title holders to ensure that they are making appropriate environmental cost deductions and also carrying out their operations according to all environmental compliance statutes. According to NEITI Report (2011), EIA implementation is a statutory responsibility of the Federal Ministry of Environment. Thus MEC collaborates with them to ensure that EIA processes like scoping and Environmental Management Plan (EMP) design are undertaken in line with the relevant regulatory frameworks. In addition, Section 19 of NMMA of 2007 postulates 
the establishment of Mineral Resources and Environmental Management Committee (MREMC) is each state of the Federation whose membership will comprise all relevant environmental stakeholders from different sectors in the individual states. MREMC works in collaboration with the MEC to ensure strict compliance with all environmental requirements (Nigerian Minerals \& Mining Act No.20, 2007).

\section{Artisanal and Small Scale Mining Department (ASSM)}

ASSM is a mechanism of government that deals with mining activities that are small scale, in an improvised form with the minimal technological application, equipment, and machinery. Section 90 of NMMA of 2007 mandates ASSM to coordinate mining activities that are restricted to less than or equal to 3 square kilometers and more than 5 acres. Similarly, Section 91 also obligates ASSM to provide extension services like modern training on mining, mineral grade testing among others to miners who are members of registered co-operatives. According to a Report by Environmental Law Institute (2014), on artisanal and small-scale mining in Nigeria, ASSM is an important department to the Nigerian mining sector particularly due to the realization that most mining activities in the country are artisanal and small-scale in nature. Large corporations in the sector are mostly into quarrying for limestone and granite. In addition, MREMC is also involved in the small-scale mining due to the localized nature of the operations. They collaborate with ASSM to ensure that all environmental issues are complied with to significantly reduce environmental impacts. Furthermore, ASSM through their extension services to artisanal miners serve as a link between miners and their host communities. They partake in resolving a dispute that may arise during mining activities and ensure that miners and mining companies do not over step their bounds.

\section{Mining Cadastre Office (MCO)}

MCO is established by Section 5 and 6 of NMMA of 2007 and mandated with the overall responsibility of administering mining titles and permits on behalf of the Federal Government of Nigeria (Nigerian Minerals \& Mining Act No.20, 2007). MCO is very exclusive and authoritative because unlike MID, MEC, and ASSM that are under the Minister, Section 15 of the Act gives $\mathrm{MCO}$ independence so as to ensure that the issuance, transfer, 
renewal and withdrawal of mineral titles and permits are carried out without fear or favor in line with the law. According to KPMG Report (2014), MCO is statutorily responsible for transfer, suspension or revocation to mining title where appropriate. It keeps an updated register with full records of all mineral titles and permits issued across Nigeria.

According to Ajumogobia \& Okeke (2015), MCO tries to ensure transparency by handling the application for mineral titles and permits on a first-come-first-served basic where those that are finally given approval are liable to lose it if they fail to comply with statutory stipulations. These titles and permits are instruments used by the government to control mining activities in Nigeria. Headquartered in Abuja Nigeria with regional offices across the Federation, MCO is has a comprehensive register of the seven categories of mineral titles and permits issuable by the FMMSD. These instruments include Reconnaissance permits, exploration licenses, mining leases, water use permits and quarry leases.

\section{Discussion}

Literature reviewed show that legislative frameworks and statutes that deal with safety consciousness during mining activities in Nigeria are scattered in different Acts and Regulations. This has been the situation since colonial days. This deduction concurs with Umeokafor (2013), Abubakar (2015) and Idowu \& Iyabo (2017) who posit that the LSHW bill of 2012 which should be the driver of safety consciousness in Nigeria is yet to be signed into law. The consequence of this is that many government enforcement agencies and departments are left to regulate themselves on safety issues with far-reaching implications. MID in the FMMSD mandated by NMMA of 2007 to enforce health and safety regulations during mines activities appears ineffective due to the extent of mining accidents and incidents which have resulted in loss of lives and reduction in environmental quality in many parts of Nigeria (Onwuemesi, Ajiwe, Okoye, Nnodu, \& Onuba, 2011; MSF, 2012; Ofoegbu, et al., 2013).

The findings of Umeokafor et al. (2014) on the massive under-reporting of accidents and injuries between 2002 and 2012 (only 133 were recorded) by the FMLE inspectorate division is a clear indication that all is not well in terms of enforcement of safety regulations in Nigeria. This is in contrast with the review done by Ezenwa (2001) between 1987 and 1996 which showed a higher record of over 3000 injuries. Even though one can argue that there might have been a significant improvement in safety management, it does not correlate with the growing Nigerian population. In addition, it does not agree with the findings of Abubakar (2015) on the lack of a comprehensive legislation and ineffective enforcement of safety regulatory frameworks. Similarly, the assertions of Umeokafor et al. (2014), Animashaun \& Odeku 
(2014) and Diugwu et al. (2012) on the corruption factor which significantly affects enforcement of safety regulatory frameworks also support the under reporting trend.

The issues raised by Adeogun \& Okafor (2013) on the rudimentary stages of safety compliance in Nigerian local companies is clearly in contrast with what is obtaining in their multinational contemporaries. This is mostly due to the fact that most of these multinational companies originate from developed countries where safety regulatory enforcement and compliance are well advanced. These assertions agree with the position of the CIS Report (2006) which pointed out there is a fewer number of safety enforcement officers in Nigeria when compared with the companies and premises they are mandated to monitor and enforce extant safety regulations. Therefore, these enforcement officers cannot be expected to perform their duties effectively when they are overwhelmed by the number of companies they are assigned to. This implies that safety enforcement agents are more susceptible bribery and corruption as posited by Umeokafor, Isaac, Jones, \& Umeadi (2014).

Many individuals know and understand what is right but still, find difficult to put it into practice. This agrees with the dimensions of consciousness as explicated in the concept of environmental consciousness (Sánchez \& Lafuente, 2010). It is not surprising that many organizations today overlook psychological safety problems in the workplace as pointed out by Kiani \& Khodabakhsh (2013). Rather they concentrate on physical ones without realizing the complex significant effects of the psychological problems on workplace efficacy and productivity. This also agrees with You-jun (2010) on the need to invest more resources to improve safety performance. Therefore, combating these psychological problems effectively require a multifaceted approach which will involve providing more resources to strengthen the overall safety management system.

The reviewed literature on the history of mining in Nigeria shows that control has also been in the hands of the government. Moreover, even though petroleum resources are mined, they are clearly demarcated from other mined mineral resources from as far back as 1916 (Annual Colonial Reports, 1907, 1914 \& 1916). This scenario has been replicated in subsequent regulatory frameworks (like Petroleum Act of 1969) in post-colonialist Nigeria which is designed with a significant preponderance to the Federal government who maintains firm control on mineral resources. In addition, successive governments and policy makers have not considered safety paramount as demonstrated by loss of lives, environmental pollution and degradation during mining activities in many parts of Nigeria (MSF, 2011; UNEP, 2011).

Reviewed legislative frameworks and regulations show that they provide reasonable measures for controlling the mining sector through the various departments and offices as well as registration and permits. However, 
implementation of these legislations and regulations may not be optimal due to the loss of lives, properties and environmental degradation as a result of mining activities in many parts of Nigeria (Nnabo, 2015; Ofoegbu et al., 2013; Oti \& Nwabue, 2013; Onyeobi \& Imeokparia, 2014; Onwuemesi et al., 2011; MSF, 2011; UNEP, 2011). This assertion agrees with Adefulu (2007) and Baba \& Egila (2012)'s position on the need to reform laws for easy interpretation, enforcement, and compliance. This is because safety regulations are likely to be useless if the status quo remains.

Literature shows that despite having abundant mineral resources, Nigeria is still battling to make the mining sector viable (Ogbonna \& Ebimobowei, 2012; KPMG, 2012; KPMG Report, 2014). However, the significant investments currently being made in the sector as pointed out by Onwuemenyi (2017) gives a glimmer of hope. However, it is relative given that achieving success this time around is debatable since previous efforts did not amount to much.

\section{Conclusion and Recommendations}

In line with the aim, the study assessed the role of government in safety consciousness during mining activities in Nigeria. Government actions and inactions have significantly affected the development of the mining sector. There are several legislative and regulatory statutes designed to control safety issues during mining activities. These statutes are quite suitable but are not wholesome because they are from different areas.

Statutes on safety during mining activities in Nigeria are not adequate enforced due to a lot of challenges that affect compliance rate by relevant stakeholders. On that note, self - regulation is now prevalent. This discretionary approach is quite unsustainable when it is unsupervised and does not necessarily demonstrate compliance with international best practices in safety management. Therefore, it is imperative to undertake a more comprehensive evaluation of safety consciousness during mining activities in order to provide more insight into how mineral mining can be carried out with the least possible harm to the miners and the environment.

In line with the conclusion, the following recommendations are made:

- The LHSW bill of 2012 should be reviewed with adequate contributions made by relevant stakeholders and passed into law as soon as possible so as to streamline safety management during mining activities and reduce disorderliness.

- Enforcement and compliance with safety regulations and frameworks must take a proactive approach to ensuring that all stakeholders are well trained in the respective roles in imbibing a positive safety culture. This will help in harmonizing their safety management systems and facilitate enforcement and compliance. 
- In other to improve safety consciousness during mining activities, regulators and mining operators should ensure that psychological disorders during mining activities are considered as relevant as physical ones. This will ensure that these 'silent' psychological disorders are also dealt with appropriately due to their significant potential to contribute to safety anomalies.

- Relevant agencies should ensure that adequate data is collected on safety parameters like mining accidents, incidents, deaths, and injuries. This will go a long way in imbibing the required safety consciousness and awareness to mitigate anomalies.

- A more comprehensive evaluation of safety and environmental consciousness is necessary in order to elucidate the issues involved in conducting mining activities safely. This will provide information on safety consciousness during mining activities and also help decision makers in the Nigerian mineral mining sector.

\section{References:}

1. Abdulkadir, B. A. (2014). The right to a Healthful Environment in Nigeria: A review of Alternative Pathways to Environmental Justice in Nigeria. Afe Babalola University Journal of Sustainable Development, Law \& Policy, 3(1).

2. Abubakar, U. (2015). An Overview of the Occupational Safety and Health Systems of Nigeria, UK, USA, Australia, and China: Nigeria Being the Reference Case Study. American Journal of Educational Research, 3(11), 1350-1358.

3. Adefulu, A. (2010). Nigeria: An Overview Of The Nigerian Minerals And Mining Act 2007. Mondaq. Retrieved from http://www.mondaq.com/Nigeria/x/95916/Mining/An+Overview+Of +The+Nigerian+Minerals+And+Mining+Act+2007

4. Adeniji, G. (2004 ). The Legal \& Regulatory Framework for Mining in Nigeria. National Mining Policy Dialogue Conference \& Exhibition July 12-14. Abuja. Retrieved from http://advisoryng.com/wpcontent/uploads/2014/04/2004.07.12.-THE-LEGAL-ANDREGULATORY-FRAMEWORK-FOR-MINING-IN-NIGERIA.pdf

5. Adeniji, G. (2007). Nigeria's Mining Act - A Case Study for Mining Reform. West Africa Mining Investment Conference. Abuja. Retrieved from http://www.aelex.com/media/files/WAMIC.pdf

6. Adeogun, B. K., \& Okafor, C. C. (2013). Occupational Health, Safety abd Environment Trend in Nigeria. International Journal of Environmental Science, Management and Engineering Research, 2(1), 24-29. 
7. Agwu, M. O., \& Olele, H. E. (2014). Fatalities in the Nigerian Construction Industry: A Case of Poor Safety Culture. British Journal of Economics, Management \& Trade, 4(3), 431-452.

8. Ajumogobia \& Okeke. (2015). Nigerian Mining Sector: Legal \& Regulatory Overview. Retrieved from http://www.ajumogobiaokeke.com/assets/media/1253c15ce97121d46 $238 \mathrm{~b} 0666 \mathrm{c} 5568 \mathrm{db} . \mathrm{pdf}$

9. Akpan, E. I. (2011). Effective Safety and Health Management Policy for Improved Performance of Organizations in Africa. International Journal of Business and Management, 6(3).

10. Alexander, U. (2012). A history of Nigerian Coal Production from 1909-2010. Journal of History and Diplomatic Studies, 9.

11. Anderson, J. (2007). Health and safety-matching legislation and enforcement. Institute of Civil Engineers Management, Procurement \& Law, 160(1), 11-15.

12. Animashaun, O., \& Odeku, K. O. (2014). Industrial Accident and Safety Hazards at the Workplace: A Spatial-Physical Workplace Approach. Mediterranean Journal of Social Sciences, 5(20).

13. Annual Colonial Report. (1907). Southern Nigeria Report No. 583. London:

HMSO.

Retrieved

from

http://libsysdigi.library.illinois.edu/ilharvest/Africana/Books201105/3064634/3064634_1907_southern_nigeria/3064634_1907_southe rn_nigeria_opt.pdf

14. Annual Colonial Report. (1914). Nigeria Report No. 878. London: HMSO.

Retrieved

from http://libsysdigi.library.illinois.edu/ilharvest/Africana/Books201105/3064634/3064634_1914/3064634_1914_opt.pdf

15. Annual Colonial Report. (1916). Nigeria Report No. 946. London: HMSO. Retrieved from http://libsysdigi.library.illinois.edu/ilharvest/Africana/Books201105/3064634/3064634_1916/3064634_1916_opt.pdf

16. Associated Press. (2014 May 14). List of Fatal Mine Disasters in Recent Years. Mail Online. Retrieved from http://www.dailymail.co.uk/wires/ap/article-2627647/List-fataldisasters-recent-years.html

17. Baiyewu-Teru, A. (2015 December 3). History: The History of Coal in Nigeria. Heinrich Böll Stiftung. Retrieved from https://ng.boell.org/2015/12/03/history-history-coal-nigeria

18. Carland, J. (1985). The Colonial Office in Nigeria, 1898-1914. Stanford: Hoover Institution Press.

19. Chindo, M. (2011). An extensive analysis of mining in Nigeria using GIS. Journal of Geography and Geology, 3(1), 3-12. 
20. CIS Report. (2006). Nigeria: Report of the National Occupational Safety and Health Information Centre (CIS). Abuja: CIS.

21. Diugwu, I. A., Baba, D. L., \& Egila, A. E. (2012). Effective Regulation and Level of Awareness: An Exposé of Nigeria's Construction Industry. Open Journal of Safety Science and Technology, 2, 140-146.

22. Ekundare, R. (1973). An Economic History of Nigeria, 1860-1960. London: Menthuen \& Co.

23. Emetumah, F. C. (2016). Appraising Management Perception of Health Safety \& Environment Culture in a Nigerian Petroleum Company. Advances in Research, 7(5), 1-15.

24. Environmental Law Institute. (2014). Artisanal and Small-Scale Gold Mining in Nigeria: Recommendations to Address Mercury and Lead Exposure. Washington, D.C.: Environmental Law Institute. Retrieved from https://www.eli.org/sites/default/files/eli-pubs/nigeria-asgmassessment-final-report.pdf

25. Ezenwa, A. O. (2001). A Study of fatal injuries in Nigerian factories. Occupational Medicine, 51(8), 485 - 489.

26. FMMSD. (2016). FEC approves 38 Vehicles for Mines Inspectorates. Federal Ministry of Mines \& Steel Development. Retrieved from http://www.minesandsteel.gov.ng/2016/11/10/fec-approves-38vehicles-mines-inspectorates/

27. Grenfell, O. (2017 May 4). At least 23 dead, dozens trapped in Iranian coal mine disaster. World Socialist Website. Retrieved from https://www.wsws.org/en/articles/2017/05/04/iran-m04.html

28. HSA Guide. (2013). Behaviour Based Safety Guide. Dublin: Health and Safety Authority.

29. Idoro, G. I. (2011). Comparing Occupational Health and Safety Management efforts and Performance of Nigerian Construction Contractors. Journal of Construction in Developing Countries, 16 (2), 151-173.

30. Idowu, M. I., \& Iyabo, V. O. (2017). Ensuring a Safe Working Environment in Nigeria: Reality or Myth. American Journal of Environmental and Resource Economics, 2(3), 107-115.

31. Kalejaiye, P. O. (2013). Occupational Health and Safety: Issues, Challenges, and Compensation in Nigeria. Peak Journal of Public Health and Management, 1(2), 16-23.

32. Kiani, F., \& Khodabakhsh, M. R. (2013). The role of safety consciousness and occupational self-efficacy in predicting physical and psychological disorders among workers of industrial sector. Journal of Kermanshah University of Medical Sciences, 17(9), 590599. 
33. KPMG. (2012). Nigerian Mining Sector. KPMG Advisory Services. Retrieved from https://www.kpmg.com/NG/en/IssuesAndInsights/ArticlesPublicatio ns/Documents/Nigerian\%20Mining\%20brief.pdf

34. KPMG Report. (2014). Nigerian Mining Sector Brief. Retrieved from http://www.kpmg.com/NG/en/IssuesAndInsights/ArticlesPublication s/Documents/Nigerian\%20Mining\%20Sector\%20Brief_v1.pdf

35. Maikori, Y. (2002). Nigeria: Minerals \& Mining Act 1999: the Need for a Review. All Africa. Retrieved from http://allafrica.com/stories/200201220319.html

36. MSF. (2012). Lead poisoning crisis in Zamfara State, Northern Nigeria. Médecins sans Frontières. Retrieved from http://www.doctorswithoutborders.org/sites/usa/files/Lead\%20Poison ing\%20Crisis\%20in\%20Zamfara\%20State\%20Northern\%20Nigeria. pdf

37. NEITI Report. (2011). Scoping Study on the Nigerian Mining Sector. NEITI. Retrieved from http://neiti.gov.ng/index.php/neitiaudits/solid-minerals/category/39-mining-scoping-studyreport?download=658:neiti-mining-scoping-study-report

38. Nigerian Minerals \& Mining Act No.20. (2007). Nigerian Minerals \& Mining Act, 2007 No.20. Retrieved from http://www.nassnig.org/document/download/5798

39. Nigerian Minerals \& Mining Regulations. (2011). . Retrieved from https://www.amla.org/images/acts/Minerals_Mines_Regulations_2011.pdf.pdf

40. Nnabo, P. (2015). Heavy Metal Distribution and Contamination in Soils around Enyigba $\mathrm{Pb}-\mathrm{Zn}$ Mines District, South Eastern Nigeria. Journal of Environment \& Earth Science, 5(16), 38-53.

41. Obiakor, N., \& Agajelu, A. C. (2016). British Colonial Economic Policies and Infrastructure in Nigeria: The Rail Transport Example, 1898 - 1960. African Journal of Arts and Humanities, 2(3).

42. Ofoegbu, C., Akubugwo, E. I., Dike, C. C., Maduka, H. C., Ugwu, C. E., \& Obasi, N. A. (2013). Effects of Heavy Metals on Soil Enzymatic Activities in the Ishiagu Mining Area of Ebonyi State-Nigeria. Journal of Environmental Science, Toxicology \& Food Technology, 5(6), 6671.

43. Ogbonna, G., \& Ebimobowei, A. (2012). Petroleum Income and Nigerian Economy: Empirical Evidence. Arabian Journal of Business and Management Review, 1(9).

44. Okafor, B., \& Nwike, E. (2016). Effects of the Land Use Act of 1978 on rural development in Nigeria: A case study of Nnobi. British Journal of Environmental Sciences, 4(3), 1-16. 
45. Onwuemenyi, S. (2017 March 30). Nigerian govt seeks \$150m World Bank loan to resuscitate mining Sector. Sweet Crude Reports. Retrieved from http://sweetcrudereports.com/2017/03/30/nigeriangovt-seeks-150m-world-bank-loan-to-resuscitate-mining-sector/

46. Onwuemesi, F., Ajiwe, V., Okoye, A., Nnodu, V., \& Onuba, L. (2011). Effect of Lead and Zinc Mining Activities on Groundwater Quality in Ishiagu, Ebonyi State, Nigeria. Journal of International Environmental Application \& Science, 6(4), 600-605.

47. Onyeobi, T., \& Imeokparia, E. G. (2014). Heavy Metal Contamination and Distribution in Soils around $\mathrm{Pb}-\mathrm{Zn}$ Mines of Abakaliki District, South Eastern Nigeria. Frontiers in Geosciences, 2(2), 30-40.

48. Oti, W., \& Nwabue, F. I. (2013). Heavy Metals Effect due to Contamination of Vegetables from Enyigba Lead Mine in Ebonyi State, Nigeria. Environment and Pollution, 2(1), 19-26.

49. Owen, R. E. (2008). One Hundred Years of Middle Eastern Oil. Middle East Brief Crown Center for Middle East Studies; University Brandeis. $\quad$ Retrieved from https://www.brandeis.edu/crown/publications/meb/MEB24.pdf

50. Raji, A. Y., \& Abejide, S. T. (2013). Shell D'Arcy exploration and the discovery of oil as important foreign exchange earning in Ijawland of Niger Delta, C. 1940s-1970. Arabian Journal of Business and Management Review, 2(11).

51. Raji, A., \& Abejide, T. S. (2014). The British Mining \& Oil Regulations in Colonial Nigeria. Singaporean Journal of Business Economics \& Management Studies, 2(10).

52. RMS. (2013). A Guide to International Health \& Safety at Work (2nd ed.). Stourbridge: RMS Publishing.

53. Sánchez, M. J., \& Lafuente, R. (2010). Defining and measuring environmental consciousness. Revista Internacional de Sociología (RIS), 68(3), 731-755.

54. Skinner, B. F. (2014). Science and human behavior. Cambridge, MA: The B. F. Skinner Foundation.

55. Tononi, G. (2008). Consciousness as Integrated Information: a Provisional Manifesto. The Biological Bulletin, 215(3), 216-242.

56. Umeokafor, N. (2017). Barriers to Construction Health and Safety Self - Regulation: A Scoping Case of Nigeria. Civil Engineering Dimension, 19(1), 44 - 53.

57. Umeokafor, N., Evaggelinos, K., Lundy, S., Isaac, D., Allan, S., Igwegbe, O., . . . Umeadi, B. (2014). The Pattern of Occupational Accidents, Injuries, Accident Causal Factors and Intervention in Nigerian Factories. Developing Country Studies, 4(15), 119 - 127. 
58. Umeokafor, N., Isaac, D., Jones, K., \& Umeadi, B. (2014). Enforcement of Occupational Safety \& Health Regulations in Nigeria: An Exploration. European Scientific Journal, 3, 93 - 104.

59. UNEP. (2011). Environmental Assessment of Ogoni Land. Retrieved from http://postconflict.unep.ch/publications/OEA/UNEP_OEA.pdf

60. Ungar, S. (1994). Apples and oranges: Probing the attitude behaviour relationship for the environment. Canadian Review of Sociology and Anthropology, 31, 288-304.

61. You-jun, W. U. (2010). Construction of Safety Performance Management System for Coal Mine Enterprises in China. Management Science and Engineering, 4(2), 40-50.

62. Zamanabadi, K. I., Kavousy, E., \& Tehrani, M. M. (2015). Hofstede's Cultural Dimensions and HSE Culture Behavior. Arabian Journal of Business and Management Review (Nigerian Chapter) 3(1).

63. Zelezny, L. C., \& Schultz, P. W. (2000). Promoting Environmentalism. Journal of Social Issues, 56, 365-371. 